\title{
Ethical And Social Responsibility In Global Marketing: An Evaluation Of Corporate Commitment To Stakeholders
}

Ephraim Okoro, Howard University, USA

\begin{abstract}
Over the past few years, globalization of markets and business organizations has increased the number of entrepreneurs and corporate executives involved in international and multinational joint ventures and strategic alliances. Others are interested in direct investments in foreign markets in an attempt to extend domestic operations, increase profit margins, and expand market shares. While these strategic business initiatives and efforts are increasingly attractive because of their potential benefits, organizations competing in global markets have to face up to the realities of committing to appropriate ethical standards and social responsibility in cross-cultural and international contexts of business.

This paper analyzes the importance of maintaining a high level of ethics in a global marketplace in order to compete successfully and to sustain consumer loyalty. Studies indicate that domestic or local conditions and expectations vary in global marketing environments because of cultural differences and values; therefore, it is critically important to adopt an ethical approach that is consistent with global business practice that can enhance credibility, corporate image, and give a competitive advantage.
\end{abstract}

Keywords: Globalization; Global Entrepreneurs; Global Economy; Corporate Social Responsibility; Marketing Ethics; Global Marketing; Global Corporate Citizenship

\section{INTRODUCTION}

$\mathrm{n}$ the twenty-first century competitive business environment, domestic and global organizations are placing a high premium on ethical decision-making and on strategic marketing communication that reflect corporate social responsibility and acceptable business practices. Scholars (Murphy et al., 2005) emphasize that the credibility of organizations is associated with the quality of communication it disseminates to stakeholders. Communicating ethically with customers, informing them correctly about the quality and content of products and services, is crucial for sustaining brand loyalty, customer satisfaction, and long-term customer retention. The international marketplace has become increasingly competitive that organizations (for-profit and notfor-profit) are now struggling to expand and sustain their market share and profit-margin. These organizations are faced with the challenge of meeting the expectations of various stakeholders who rely on the information provided to make buying decisions.

The ongoing debate among researchers (Shaw, 1997; Schwepker \& Hartline, 2005) is that business organizations competing in the global marketing environments should demonstrate their ethical commitment by ensuring that their target audiences receive credible information regarding product content and functions. For example, the International Chamber of Commerce (the world's business organization) consistently promotes high standards of business ethics through the development and dissemination of rigorous rules, including specific guidelines and codes on how organizations should conduct their business practices and activities around the world to ensure that marketing messages are responsible, dependable, and ethical. 
Studies (Kennedy et al., 2001; Futrell, 2002) state that strategic and responsible marketing messages should be designed to assist consumers to buy the quality and type of items they really need. For instance, a sound advertising message should guide a consumer's choice in selecting food and beverage products and in evaluating the role of nutrition, diet, and physical activity in healthy styles. The Direct Selling Education Foundation (2009) reported that the International Chamber of Commerce suggested the need for organizations to develop efficient advertising messages that are consistent with good nutrition, diet, and personal choices. By doing this, organizations play a critical role in establishing trusting and lasting relationships with consumers and will ultimately gain their confidence.

In the last decade, the international food and beverage community has placed increasing emphasis on customers' diets, health and fitness, and physical activity. This consumer-centered commitment has resulted in the development of a framework for responsible food and beverage marketing message that is self-regulated and monitored.

Further, as noted by the Direct Selling Education Foundation (2009), self-regulation serves the interest of consumers and other stakeholders of organizations by preventing false and misleading advertising claims. Consistently, research shows that accurate marketing communication, guided by self-regulation, is legally expected and required to compete effectively in today's global marketplace. Marketing practitioners (Murphy, 1999; Pagano et al, 2005) explained that a responsible marketing message is a significant organizational commitment as it helps consumers to make appropriate choices about products and services and to avoid negative post-purchase reactions. To a large extent, pre-purchase and post-puchase consumer decision and evaluation is the product of marketing communication.

\section{CORPORATE SOCIAL RESPONSIBILITY}

In the wake of globalization, global business experts and marketing researchers (Lawrence \& Weber, 2011; Abela \& Murphy, 2008; Kotler, 2004) have highlighted the need for honest interactions with organizations' stakeholders in order to achieve social good and economic goals simultaneously. It is noted that an attempt by corporations to expand market share and profit margins, at the expense of their consumers, compromises their integrity and places them at a competitive disadvantage in the global markets. The concept of corporate social responsibility has become a critical focus as organizations extend their reaches far beyond their domestic environments. Indeed, businesses with subsidiaries and joint ventures in other countries of the globe should conduct their businesses in ways that enhance or contribute to the well-being of societies in which they are doing business. As studies by Pagano, Pagano, \& Lundin (2003) emphasized, being socially responsible is a commitment that multinational corporations are required to embrace in order to remain competitive. As corporations locate their businesses in foreign countries, it has become a core strategic imperative to position and differentiate themselves as ethically responsible and committed in order to increase their global competitiveness. In keeping with this perspective, O'Sullivan \& Abela (2007) and Lawrence \& Weber (2011) state that to attract and retain global consumers, sustain brand loyalty, and outperform competitors, organizations should avoid seeking excessive profits that hurt their stakeholders, undermine their positioning strategies, and diminish their credibility. In the contemporary business context, business success is measured by growth and expansion in global markets and by the ability to exercise what authors Lawrence \& Weber (2011) describe as "corporate power and responsibility."

As Table 1 indicates, large corporations play an important role in the global context of business. The power and influence exerted by large organizations has serious ramifications in global economies. The influence exerted by corporations (corporate power) supports their various stakeholders in the countries in which they conduct business. Lawrence \& Weber (2011) described corporate power as a function of size and resources of corporations, and their ability to demonstrate ethical commitment and responsibility in global ventures. Table 1 indicates that the "big five" global corporations in the year 2009, measured by size, were Wal-Mart, ExxonMobil, Royal Dutch Shell, BP, and Toyota Motor. The table also noted that the three most profitable companies in the top 10 were in the petroleum industry: Exxon-Mobil, Royal Dutch Shell, and BP (during the period of global rising oil prices). 
Table 1: The 10 Largest Global Corporations, 2009

\begin{tabular}{|c|l|c|c|}
\hline Rank (by Revenue) & Company/Corporation & Revenues (U.S. \$millions & Profits (U.S. \$millions) \\
\hline 1 & Walmart Stores & $\$ 378,799$ & $\$ 12,731$ \\
2 & ExxonMobil & 372,824 & 40,610 \\
3 & Royal Dutch Shell & 355,782 & 31,331 \\
4 & BP & 291,201 & 20,845 \\
5 & Toyota Motor & 230,201 & 15,042 \\
6 & Chevron & 210,783 & 18,688 \\
7 & ING Group & 201,516 & 12,649 \\
8 & Total & 187,280 & 18,042 \\
9 & General Motors & 182,347 & $-38,732$ \\
10 & ConocoPhilips & 178,558 & 11,891 \\
\hline
\end{tabular}

Source: "Fortune Global 500" CNN Money.Com

Discussing the concept of "business ethics and marketing with integrity," Abela and Murphy (2008) noted that despite extensive and thoughtful efforts focused on ethical business practices, there have been constant ethical violations by a number of businesses in many industries in recent years. Indeed, the inability or failure of organizations to market their products and services in a manner that does not compromise the trust of consumers has been a subject of great debate. Researchers (O'Sullivan et al., 2007) blame unethical business practices on different business approaches and tactics necessitated by globalization, which make competing organizations applying different standards, rules, and guidelines. Other studies focusing on global marketing (Ferrell, 2004; Schwepker et al., 2005) noted that ethical violations are practiced by organizations without integrity and good image. Their primary focus is to exploit consumers with misinformation, deception, and exaggerations of product content. Based on assessment of business practices across organizations, Murphy et al. (2005) and Snyder \& Showm (2011) determined that appropriate business ethics should involve high moral standards, consistent organizational goals, and strategic decisions in advertising goods and services to consumers, including the choice of channels and incentive sales promotion.

While the current domestic and global marketing environments have been exceedingly competitive, especially with new products and services in many industries, it is exceedingly critical that organizations should do what is right for their customers. Essentially, sales should be driven by ethical values and moral standards, and consumers should be accurately informed in order that they can make good purchase decisions. Research findings (Waddock, 2002; Griffin \& Erbert, 2006) indicate that post-purchase experience of some consumers has not only been disappointing because of consistent deception and misinformation that have characterized advertising campaigns, but has seriously discouraged consumers from trusting marketing information and messages. For example, writing under "Truth in advertising," Rados (2009) noted that Direct-to-Consumer (DTC) advertising of prescription drugs was used in the United States and in many other parts of the world. While this channel has helped significantly in reminding patients to get their prescriptions refilled on time and guided them with medication regimens, it is an ethical responsibility of organizations to ensure that consumers (patients) are not misled by unethical promotional messages and data.

In recent decades, sales and advertising have been considered critical business functions charged with the responsibility of interacting with stakeholders, raising their awareness about product qualities, and establishing organizational good will. Further, studies across management and marketing disciplines (Waddock, Bodwsell, \& Graves, 2002; Altham, 2001) emphasize that organizations that want to make themselves more competitive and relevant in the new global economy must consistently use ethical messaging so that their consumers can make good product decisions. Success in the global marketplace should no longer be taken for granted because target audiences and market segments of the twenty-first century are better educated and knowledgeable about consumer rights and expectations. It should, therefore, be noted that consumers are inclined to support organizations that show commitment in relationship marketing across nations. 


\section{GLOBAL CORPORATE CITIZENSHIP}

Researchers have expanded their discussions of ethical responsibility and commitment to consumers with an emphasis on the concept of "global corporate citizenship." Lawrence \& Weber (2011) contend that putting corporate commitment to social and environmental responsibility into global practice gives organizations a strategic advantage in their efforts to expand business scope and profitability. The authors specifically stressed that "corporate citizenship has become increasingly global in scope, reflecting the global nature of commerce and merging awareness of the worldwide scope of many social issues" (p.147). Ultimately, organizational commitment to serving their stakeholders with integrity underscores the meaning of global corporate citizenship, which corporations in international business and marketing should practice in order to remain successful.

Kotler (2004) states that ethical marketing involves strategic and systematic coordination of the variables of product, price, place, and promotion, referred to as the "4-Ps of marketing," to efficiently and effectively manage the various needs and wants of stakeholders. Therefore, concept of corporate social responsibility has been a fundamental business concern because of the growing unethical tendencies and practices of business organizations. Repeated incidents of misleading or dishonest advertising messages and campaigns have called organizational integrity into question and cast a shadow of doubt over marketing roles in the business environment. With globalization driving contemporary economic development, the importance of establishing a business culture that encourages dissemination of ethical messaging and socially responsible business practices should be a required commitment. Additionally, O'Sullivan \& Abela (2007) stressed the need for customer relationship marketing that is strongly guided by sound moral principles and objective communication. As a core aspect of business operation and activity that is most visible to consumers, marketing activities and processes should be driven by high ethical values in a free-enterprise system in many developed economies.

In an assessment of organizations' responsibilities, commitments, and contributions to the well-being of global consumers, Kotler (2004) and Schwepter \& Hartline (2005) acknowledged that ethical business organizations are well commended and respected by their target market and are proud of maintaining their commitment. These organizations constantly search for unmet needs, encourage the development of products that address critical human needs, manage advertising messages to inform consumers about new products and services, and arrange for accessibility and availability of goods. Committed organizations should set prices for their goods in a way that represents superior value delivered vis-à-vis competitors' offerings. It stands to reason that credible organizations can do what is right in a competitive environment, make a profit, and expand and sustain their market growth. Misleading or misinforming customers via unethical communication does not only tarnish corporate image, but it also creates consumer suspicion and diminishes consumer loyalty in the long run.

Doing what is right through ethical communication is a strategic direction for not-for-profit and for-profit organizations. For one thing, the dividend that accrues from it has a lasting effect on the sustainability of organizations' image and their positioning in the marketplace. A commitment to honest business practices and devotion to adequately informing consumers about the quality of products and services without embellishment or exaggeration of critical elements of brand quality has the advantages of being able to retain current customers as well as attract new ones. Consequently, consumers' trust is earned by organizations which ultimately results in expanded market share, competitive advantage, and increased profitability for organizations. Studies (Jamal \& Kamal, 2003; Futrell, 2002) indicate that customer-focus is the new emphasis in the rapidly changing marketing environment because giving a false impression of any kind to promote or sell a product or service places an organization's survival in a precarious situation. Effective communication and ethical business practice indicate that marketing communicators are clearly mindful of the need to provide honest and truthful information about products, make consumers fully aware of available choices, and enable them to make their choices based on needs, tastes, and priorities.

To demonstrate total commitment or concern for the well-being of organizations' stakeholders, Ferrell (2004) suggests that organizations should reject high pressure manipulations, or misleading sales tactics, avoid sales promotions that employ deception or manipulation, and desist from false and misleading advertising campaigns. There should be a need to establish business code of ethics upon which communication with customers is based. Further, Manning and Reece (2004) concluded that ethics has a strong influence on consumers' perceptions of 
quality and integrity in their relationship with organizations. Most importantly, being able to depend on organizations delivering on their promises and feeling that businesses and sales associates will provide honest feedback is central to developing a trusting relationship with global organizations.

Gaining and sustaining competitive advantage in the globalized economy, organizations of all sizes should deliver satisfaction to customers, and show ethical commitment in their marketing communication. As Abela and Murphy (2008) noted, there is a positive correlation between organizational growth and ethical responsibility because consumers tend to patronize organizations with a profound sense of ethical standards. Consumers are increasingly interested in receiving satisfaction from sales transactions and will continue to support businesses that are grounded in strong ethics.

Consumers and other stakeholders have increased their attention to advertising ethics, product information, and positioning strategies used by organizations to compete because of controversies and inconsistencies associated with promotional messages. For example, Griffin and Ebert (2006) pointed out that as a result of misinterpretation of words and phrases, such as "light, reduced calorie, diet, and low fat," food producers are required to use standardized format and nomenclatures for listing ingredients on product packages. This measure would ensure that consumers are well informed about product and service content and functions. Usage procedures, standards, and warnings of credible and responsible organizations should be disseminated through many channels to their target audience. It is therefore necessary that marketing communications to stakeholders should be framed clearly and precisely enough to guide their behaviors and foster appropriate purchase decisions.

A review of the Millennium Pool Chart on Ethics and Corporate Social Responsibility, which surveyed approximately 25, 000 consumers in 23 countries, indicates citizens' expectations of domestic and global organizations.

In ten countries listed in Table 2, citizens were strongly concerned in seeing organizations establish high ethical standards in their relationships with people and society in general. Specifically, in Australia, Canada, Mexico, Great Britain, and the United States, the level of peoples' concern and expectation for organizational ethical commitment is remarkably high, which indicates the significance of business ethics and corporate social responsibility in global business environments.

Table 2: Millennium Pool Chart on Social Responsibility

\begin{tabular}{|l|c|c|c|}
\hline \multicolumn{1}{|c|}{ Countries } & $\begin{array}{c}\text { Make Profit, Pay Taxes, } \\
\text { Create Jobs, \& Obey Laws }\end{array}$ & $\begin{array}{c}\text { Operate Between the Two } \\
\text { Positions }\end{array}$ & $\begin{array}{c}\text { Set high Ethical Standards } \\
\text { \& Improve Society }\end{array}$ \\
\hline Australia & $8 \%$ & 435 & $45 \%$ \\
\hline Canada & $11 \%$ & $45 \%$ & $43 \%$ \\
\hline Great Britain & $17 \%$ & $42 \%$ & $39 \%$ \\
\hline Mexico & $25 \%$ & $26 \%$ & $35 \%$ \\
\hline Japan & $32 \%$ & $18 \%$ & $33 \%$ \\
\hline Germany & $33 \%$ & $31 \%$ & $43 \%$ \\
\hline South Africa & $35 \%$ & $23 \%$ & $34 \%$ \\
\hline $\begin{array}{l}\text { China } \\
\text { Russia }\end{array}$ & $44 \%$ & $31 \%$ \\
\hline United States & $28 \%$ & $22 \%$ & $23 \%$ \\
\hline $\begin{array}{l}\text { Selected results from poll identifying citizens' expectations of organizations } \\
\text { (by percentage of respondents) }\end{array}$ & $23 \%$ & $35 \%$ \\
\hline
\end{tabular}

Source: J. Altham International Business Ethics, 2001.

Discussing efficient marketing communication as a way to help consumers learn, Wernerfelt (1996) stressed that as a measure of organizational commitment, consumers" awareness should be "about more, rather than less, important attributes" of a product or service. By providing needed information, consumers are better able to make intelligent purchase decisions. The author cautions against the shortsightedness of organizations, specifically food sellers, to suppress or minimize information about calories, percentages of ingredients, and side effects. It is 
critically important that information about product functions and side effects be fully disclosed to consumers, which raises the level of consumer confidence.

\section{CONCLUSION}

Ethical commitment and responsibility is an important business practice that should be adequately demonstrated to all stakeholders (consumers/customers/clients). Studies indicate that organizations that provide honest information to their consumers reap lasting rewards, ranging from brand loyalty, customer satisfaction and retention, to expanded market share. As Murphy et al. (2006) stressed, consumers and organizations are in a symbiotic marketing relationship that rests on the premise that they are in a long-term partnership based entirely on trust and strongly grounded in the marketing concept. Finally, Shaw (1997) discusses the concept of "Trust in the Balance", rationalizing that organizations should communicate to stakeholders in such a way that they perceive product and service claims as honest and that they can be relied upon. Additionally, the author stresses that integrity and consistency are critical elements in a seller-buyer relationship and that the well-being of consumers should always be kept in fair balance with the interest of corporations. Studies have endorsed that ethical marketing relationships engender a great deal of trust and commitment in global marketing. Over a decade ago, Morgan \& Hunt (1994) and Rado (2004) demonstrated a strong link between commitment and trust in domestic and international business transactions.

\section{AUTHOR INFORMATION}

Ephraim A. Okoro, $\mathrm{PhD}$ is an assistant professor of business communication and marketing at Howard University. His research interests probe the interface between intercultural communication and workforce diversity in the context of globalization. He teaches business communication, marketing communication, management communication, and principles of marketing. Address correspondence to Dr. Ephraim Okoro, Department of Marketing, School of Business, Howard University, 2600 - Sixth Street, NW, Washington, D.C. 20059; E-mail: eaokoro@howard.edu. (202) 806-1545

\section{REFERENCES}

1. $\quad$ Abela, A.V \& Murphy, P. E. (2008). Journal of Academic Marketing Journal Science, 36:39-53.

2. Altham, J. (2001). Business Ethics versus Corporate Social Responsibility: Competing or Complimentary Approaches? Environics International Limited, The Prince of Wales Business Leaders Forum and the Conference Board, International Business Ethics Institute, Washington, D.C: www.business-ethics.org.

3. Direct Selling Education Foundation (2009). The Business Ethics Forum, The University of Texas at Arlington, College of Business, October 15-16.

4. Ferrell, O.C. (2004). Business and Customer Satisfaction. Academy of Management Executive, 18, Number 2 (May), pages 126-129.

5. Futrell, C. M. (2002). Fundamentals of Selling: Customers for Life, $7^{\text {th }}$ Edition, New York: McGraw-Hill.

6. Griffin, W.W. \& Ebert, R. J. (2006). Business. $8^{\text {th }}$ Edition. Prentice-Hall, Upper Saddle River: New Jersey.

7. Kennedy, M.S., Ferrell, L.K. and Leclair, D.T. (2001) "Customers Trust of Salesperson and Manufacturer: An Empirical Study," Journal of Business Research, 51: 73-86.

8. Kotler, P (2004). Marketing Management, (November/December), American Marketing Association, pp. 30-35.

9. Manning, G. L. and Reece, B. L. (2004). Selling Today, $9^{\text {th }}$ Edition, Prentice Hall: New Jersey.

10. Morgan, R.M. \& Hunt, S.D. (1994). "The Commitment-Trust Theory of Relationship Marketing.” Journal of Marketing, volume 58, pp. 20-38.

11. Murphy, P. E. (1999). Character and Virtue Ethics in International Marketing: A Agenda for Managers, Researchers, and Educators. Journal of Business Ethics, 18, 107-124.

12. Murphy, P. E., \& Laczniak, G. R. (1981). Marketing Ethics: A Review with Implications for Managers, Educators, and Researchers. In B. M. Enis \& K. J. Roering (Eds.), Review of Marketing, Chicago: American Marketing Association.

13. O'Sullivan, D., \& Abela, A. V. (2007). Marketing Performance Measurement Ability and Firm Performance. Journal of Marketing, 71, 79-93. 
14. Pagano, B., Pagano, E., \& Lundin, S. (2003). The Transparency Edge: How Credibility Can Make or Break You in Business. New York: McGraw-Hill.

15. Rado, C. (2004). Truth in Advertising: Rx Drug Ads Come of Age. FDA Consumer, July/August.

16. Shaw, R. B. (1997). Trust in Balance: Building Successful Organizations on Results, Integrity, and Concern. San Francisco, CA: Jossey-Bass Publishers.

17. Schwepker, C. H., \& Hartline, M. D. (2005). Managing the Ethical Climate of Customer-Contact Service Employees. Journal of Service Research, 7(4), 377.

18. Shwom, B. \& Gueldenzoph Snyder, L (2012) Business Communication: Polishing Your Professional Presence. New York: Pearson Publishers, Inc.

19. Waddock, S. A., Bodwell, C., \& Graves, S. B. (2002). Responsibility: The New Business Imperative. Academy of Management Executive, 16(2), 132.

20. Wernerfelt, B (1996, May). Efficient Marketing Communication: Helping the Customer Learn. Journal of Marketing Research. Volume xxxiii, 239-246. 
NOTES 